Nutr. Metabol. 1975;18:I-V

\title{
Contents, Vol. 18, 1975
}

\section{Nutrition and Metabolism}

Journal of Nutrition, Metabolic Diseases and Dietetics

N. Zöllner, Munich

E.M. Widdowson, Cambridge G. Wolfram, Munich

Main Editor Associate Editors

Editorial Board

W. Auerswald, Vienna

K.J. Carpenter,

Cambridge

H.-D. Cremer, Giessen

I. W. T. Dickerson,

Guildford

F. Falkner,

Yellow Springs, Ohio

F. Fidanza, Perugia

R. Gitzelman, Zurich G. Hartmann, Chur C. Den Hartog, Rijswijk K. Hellström, Stockholm S. Heyden, Durham, N.C. F.A. Hommes, Groningen B. Jacotot, Créteil H. Kapp, Basel E. Kodicek, Cambridge

/. Macdonald, London H.K. Mangold, Münster K.R. Norum, Oslo G. Schlierf, Heidelberg J.C. Somogyi, Zurich /. Trémolières, Paris A.J. Vergroesen, Vlaardingen-Duiven A. Wretlind, Stockholm

S. Karger $\cdot$ Basel $\cdot$ München $\cdot$ Paris $\cdot$ London $\cdot$ New York $\cdot$ Sydney

S. Karger · Basel · München · Paris · London · New York · Sydney Arnold-Böcklin-Strasse 25, CH-4011 Basel (Switzerland)

All rights, including that of translation into other languages, reserved. Photomechanic reproduction (photocopy, microcopy) of this volume or parts thereof without special permission of the publishers is prohibited.

(C) Copyright 1975 by S. Karger AG, Verlag für Medizin und Naturwissenschaften, Basel Printed in Switzerland by Thür AG Offsetdruck, Pratteln

Index

No. 1

Editorial

Heyden, S. (Durham, N.C.): The Problem with Triglycerides

Original Paper

Mahoney, A.W. and Hendricks, D.G. (Logan, Utah): Utilization of Dietary Calcium by Iron-Deficient Rats 6

Pieniazek, D.; Grabarek, Z., and Rakowska, M. (Warsaw): Quantitative Determination of the Content of Available Methionine and Cysteine in Food Proteins 16 Subbiah, M.T.R.; Kottke, B.A.; Carlo, LA., and Naylor, M.C. (Rochester, Minn.): 
Human Intestinal Specificity toward Dietary Sterols Studied by Balance Methods. 23 Nettleton, J.A. and Hegsted, D.M. (Boston, Mass.): Protein-Energy Interrelationships during Dietary Restriction: Effects on Tissue Nitrogen and Protein Turnover ... 31 Hazinski, T.A.; Ban, M., and Hertelendy, F. (St. Louis, Mo.): Adipose Tissue Metabo lism in Essential Fatty Acid Deficiency. Effects of Prostaglandin E, , Epinephrine, and $\mathrm{ACTH} \quad 41$

Basu, T.K.; Dickerson, J.W.T., and Parke, D.V. (Guildford): Effect of Protein/Energy Nutrition on Rat Plasma Corticosteroids and Liver Microsomal Hydroxylase Activity $\quad 49$

Book Review $\cdot$ Buchbesprechung $\cdot$ Livre nouveau 55 Varia 56

No. 2

Golubovic Curcic, V. and Curcic, B. (Sarajevo): Effect of Vitamin D on Serum Choles terol and Arterial Blood Pressure in Infants 57

Rambaut, P.C.; Leach, C.S., and Johnson, P.C. (Houston, Tex.): Calcium and Phos phorus Change of the Apollo 17 Crew Members 62

Holub, B.J. (Guelph, Ont.): The Effect of Dietary Protein Levels on the Rate of Lipid Biosynthesis from Glycerol-3-Phosphate in Rat Liver $\quad 70$

Shih-Ching Lee and Mong-Lan Wang (Taipei): Histidinemia Produced in the Rat by Treatment with Nitromethane 79

Index IV

Topping, D.L $\cdot$ and Turner, DM. (Harrogate): Plasma Triglyceride Secretion in Squirrel Monkeys: Effects of Nicotine $\quad 89$

Galfsky, I.; Wollinsky, I.; Simkin, A., and Guggenheim, K. (Jerusalem): Effect of Repletion with Dietary Calcium on Composition and Mechanical Properties of Bone of Calcium-Deprived Rats 99 Girard, V. et Prabucki, A.L. (Zurich): Action de la flore intestinale sur la sévérité des symptômes de carence en acides gras essentiels chez la caille (Coturnix cot. jap.) (The Role of the Intestinal Flora on the Severity of the Symptoms of Essential Fatty Acid Deficiency in Quail [Coturnix cot. jap.]) 105

Varia 112

No. 3

Editorial

Pahlke, G. (Berlin): Dietary Fat and Degenerative Vascular Diseases 113

Original Paper Thiessen, D.D.; Ondrusek, G., and Coleman, R.V. (Austin, Tex.): Vitamin E and Sex

Behavior in Mice 116

Fisher, H.; Konlande, J., and Strumeyer, D. (New Brunswick, N.J.): Levels of Histidine and Histidine Derivatives in Breast Muscle of Protein-Depleted and Repleted Adult Cockerels $\quad 120$

Zöllner, N.; Ruckdeschel, G. und Wolfram, G. (München): Verhalten der Darmflora des Menschen bei Formeldiäten mit wechselndem Kohlenhydratgehalt (Effects of Conventional Food and of Formula Diet on Gut Microflora) 127

Drevon, Ch.A. and Norum, K.R. (Oslo): Cholesterol Esterification and Lipids in Plasma and Liver from Newborn and Young Guinea Pigs Raised on Milk and Non-Milk

Diet 137 
Lai, H. and Agarwal, K.N. (Varanasi): Influence of Carbohydrate-Free Protein-Rich

Diet on Free $\alpha$-Amino Nitrogen Changes in Plasma. Erythrocytes and Leucocytes. 152 Schwarz, F.J. und Kirchgessner, M. (Freising-Weihenstephan): Tierexperimentelle

Untersuchungen zur Zn-Absorption bei verschiedenen Dünndarmabschnitten und

Zn-Verbindungen

(Experimental Studies on the Absorption of Zinc from Different Parts of the

Small Intestine and Various Zn Compounds) 157

Book Reviews · Buchbesprechungen — Livres nouveaux 167

No. 4

Gelman, R.A. and Gübertson, J.R. (Pittsburgh, Pa.): Permeability of the Blood-Brain

Barrier to Long-Chain Alcohols from Plasma 169

Fidanza, F. and Fidanza Alberti, A. (Perugia): Food and Nutrient Consumption on

Two Rural Population Groups of Italy Followed for Ten Years 176

Index

$\mathrm{V}$

Holm, H.; Hustvedt, B.E., and L $\varphi v o$, A. (Oslo): Protein Metabolism in Rats with

Ventromedial Hypothalamic Lesions: Dietary Effects on Nitrogen Retention . 190

Evans, E. and Miller, D.S. (London): Bulking Agents in the Treatment of Obesity ... 199

Pao, S.-K. and Dickerson, J.W.T. (Guildford): Effect of a Low Protein Diet and Isoenergetic Amounts of a High Protein Diet in the Weanling Rat on the Free Amino Acids of the Brain 204

Sperling, O.; Boer, P.; Brosh, S.; Elazar, E.; Szeinberg, A., and Vries, A. de (Petah Tiqva): Normal Activity of Metabolic Pathways Involved in the Formation and Utilization of Phosphoribosylpyrophosphate in Erythrocytes of Patients with

Primary Metabolic Gout 217

Book Review · Buchbesprechung - Livre nouveau 224

No. 5-6

Lacord-Bonneau, M.; Picard, J. et Dubernard, L. (Paris): Influence de la vitamine A sur la distribution des glycosaminoglycanes dans les tissus du rat (Influence of Vitamin A on Distribution of Glycosaminoglycans in Rat Tissues). . 225

Nitsan, Z. and Liener, I.E. (St. Paul, Minn.): Levels of Urea in the Blood and Urine of Rats Fed Raw and Heated Soybean Meal 240

Sharpe, G.L.; Larsson, K.S., and Liedén, S.-Å. (Stockholm/Uppsala): Toxicological and Teratological Studies of a Rapeseed Protein Diet in Rats and Mice 245

Ecklund, A. (Uppsala): Effect of Chlorogenic Acid in a Casein Diet for Rats. Nutri tional and Pathological Observations 258

Sheltawy, M.J. and Losowsky, M.S. (Leeds): Effect of Non-Ionic Detergents on the Absorption of Fat and $\alpha$-Tocopherol in the Rat 265

Michalek, H.; Carmine, R. del, and Gatti, G.L. (Rome): Effect of Dietary Rapeseed Oil on Hepatic Hexobarbital Metabolism in Mice 272

Macdonald, I.; Rebello, T., and Keyser, A. (London): An Investigation in Rats, into the Metabolic Consequences of Early Ingestion of Dietary Carbohydrates 283

Horton, B.J.; West, C.E., and Turley, S.D. (Canberra): Diurnal Variation in the Feeding Pattern of Guinea Pigs 294

Basu, T.K.; Dickerson, J.W.T., and Parke, D. V. (Guildford, Surrey): Effect of Dietary Substitution of Sucrose and its Constituent Monosaccharides on the Activity of 
Aromatic Hydroxylase and the Level of Cytochrome P-450 in Hepatic Microsomes of Growing Rats 302

Mahoney, A.W.; Holbrook, R.S., and Hendricks, D.G. (Logan, Utah): Effects of Cal cium Solubility on Absorption by Rats with Induced Achlorhydria 310

Rao, S.B.; Raghuram, T.C., and Krishnaswamy, K. (Hyderabad): Role of Vitamin B6 on Leucine-Induced Metabolic Changes 318

Varia 326

Author Index 327

Subject Index 328 